\title{
PENGARUH KARTU PINTAR BENCANA TERHADAP SIKAP KESIAPSIAGAAN BENCANA PADA ANAK SEKOLAH DI KOTA TANGERANG TAHUN 2018
}

\author{
Siti Wasliyah, Kusniawati \\ Poltekkes Kemenkes Banten \\ Korespondensi: els.siti@gmail.com
}

\begin{abstract}
The National Disaster Management Agency (BNPB) noted that from January to March 2017 there had been 883 disasters throughout Indonesia. Banten is a disaster-prone area, where more than 10 types of disasters are prone to occur in the Banten and surrounding areas. In the regional disaster risk index assessment two regions in Banten that have a score above 150 points are Lebak and Pandeglang Regencies. (BNPB, 2017). The development of smart cards on disaster management will begin in this study, with the hope that strategies for improving attitudes in the face of disasters can reach up to school children. This research is a quasi-experimental study using the pretest and postets group design approach, aimed at identifying the effect of disaster card use in improving disaster preparedness attitudes in elementary school children. The research was conducted at Taman Sukarya State Elementary School in Kota Tangerang in June November 2018 with a student population at Taman Sukarya Elementary School. The sampling method used was consecutive sampling totaling 50 people for each intervention and control group. The mean attitude in the group using the card (intervention) was 36.28 with a standard deviation of 4.36. In the group given no intervention was obtained the attitude average was 0.26 with a standard deviation of 0.75 . The statistical test results obtained a $P$ value of 0.734 ( $P$ value $<0.05$ ), it can be concluded there is no significant difference between the mean attitudes of the intervention group and the control group. Disaster cards can be used as reading vehicles and games that contain information about disasters even if they do not improve the attitude of disaster preparedness in elementary school children.
\end{abstract}

Keywords: Smart Cards, Disaster Management

\begin{abstract}
ABSTRAK
Badan Nasional Penanggulangan Bencana (BNPB) mencatat pada bulan Januari sampai Maret tahun 2017 telah terjadi 883 bencana di seluruh Indonesia. Banten merupakan daerah rawan bencana, dimana lebih dari 10 jenis bencana, rawan terjadi didaerah banten dan sekitarnya Pada penilaian indeks risiko bencana daerah dua wilayah di Banten yang memiliki skor di atas 150 poin adalah Kabupaten Lebak dan Pandeglang.(BNPB, 2017). Pengembangan kartu pintar mengenai penanggulangan bencana akan mulai dilakukan pada penelitian ini, dengan harapan strategi peningkatan sikap dalam menghadapi bencana dapat menjangkau sampai anak sekolah. Penelitian ini adalah penelitian kuasi eksperimen dengan pendekatan pretest and postets group design, bertujuan untuk mengidentifikasi pengaruh penggunaan kartu bencana dalam meningkatkan sikap kesiapsiagaan bencana pada anak sekolah dasar. Penelitian
\end{abstract}


dilakukan di Sekolah Dasar Negeri Taman Sukarya di Kota Tangerang pada bulan Juni Nopember 2018 dengan populasi siswa SDN Taman Sukarya. Metode sampling yang digunakan adalah consecutive sampling berjumlah 50 orang untuk masing-masing kelompok intervensi dan kontrol. Rerata sikap pada kelompok yang menggunakan kartu (intervensi) adalah 36,28 dengan standar deviasi 4,36. Pada kelompok yang diberikan tidak diberikan intervensi didapat rata-rata sikap adalah 0,26 dengan standar deviasi $0,75$. Hasil uji statsitik diadapatkan nilai $P$ value 0,734 ( $P$ value $<0,05)$ maka dapat disimpulkan tidak ada perbedaan yang signifikan antara rata-rata sikap kelompok intervensi dan kelompok kontrol. Kartu bencana dapat digunakan sebagai wahana baca dan permainan yang mengandung informasi tentang bencana walaupun tidak meningkatkan sikap kesiapsiagaan bencana pada anak sekolah dasar.

\section{Kata Kunci: Kartu Pintar, Penanggulangan Bencana}

\section{PENDAHULUAN}

Iklim Indonesia sangat dipengaruhi oleh lokasi karakteristik geografis. Pola iklim yang berbeda menyebabkan perbedaan dramatis dalam pola curah hujan di Indonesia. Karena posisi geografis dan lokasinya yang berada di salah satu bencana paling aktif di dunia.(Kemendikbud, 2015). BNPB mencatat pada bulan Januari sampai Maret tahun 2017 telah terjadi 883 bencana di seluruh Indonesia. Banten merupakan daerah rawan bencana, dimana lebih dari 10 jenis bencana, rawan terjadi didaerah banten dan sekitarnya Pada penilaian indeks risiko bencana daerah dua wilayah di Banten yang memiliki skor di atas 150 poin adalah Kabupaten Lebak dan Pandeglang.(BNPB, 2017). Kota Tangerang merupakan salah satu daerah rawan bencana di Banten dimana sebelah utara berbatasan dengan kecamatan Teluk Naga yang terdapat pantai (bencana tsunami dan gempa bumi), sebelah selatan berbatasan dengan kecamatan curug tempat pendidikan penerbangan dimana letak bandara Internasional juga berada dekat dengan kota Tangerang berpotensi terjadi bencana kecelakaan pesawat, sebelah barat berbatasan dengan kecamatan Cikupa Kabupaten Tangerang yang banyak terdapat pabrik industri. Letak Kota Tangerang yang sangat strategis karena berbatasan langsung dengan ibukota Negara DKI Jakarta menyebabkan Tangerang juga berpotensi untuk menjadi rawan bencana biologis., merupakan rawan bencana industri.

Pemerintah Indonesia menetapkan Undang-Undang No.24 Tahun 2007 tentang Penanggulangan Bencana yang menekankan bahwa penanggulangan bencana tidak hanya terpaku pada tahap tanggap darurat/respons saja tetapi juga mencakup tahap pra bencana (kesiapsiagaan) dan pasca bencana 
(pemulihan). Elemen-elemen dalam kesiapan bencana meliputi pengetahuan personal, komunitas dan tingkat nasional. Elemen lain yang tidak kalah penting antara lain pendidikan bencana, dampak respon bencana dan pengembangan respon lokal seperti sistem peringatan dini (early warning system) sebagai bagian penting kesiapan bencana. (Clust,Human \& Simpson, 2007). Beberapa penelitian membuktikan bahwa intervensi berbasis sekolah meningkatkan pengetahuan bencana teoritis yang mungkin juga mencakup keterampilan praktis; Namun, belum tentu merubah perilaku bencana. Hasil terbaik akan diperoleh dengan menggabungkan kegiatan teoritis dan praktis di sekolah, keluarga, masyarakat, dan program pendidikan mandiri. Kebutuhan mendesak untuk dorongan pendidikan terpadu untuk mencapai perubahan perilaku adaptif terhadap kesiapsiagaan bencana sangat dibutuhkan untuk meningkatkan peluang bertahan hidup bagi korban bencana. (Codeanu TA, Celenza TA, Jacobs, 2014).

Peristiwa 26 Desember di Aceh menunjukkan bahwa anak-anak adalah kelompok yang paling rentan terhadap bencana alam. Sebelumnya anak-anak dianggap sebagai "korban pasif”. Saat ini anggapan tersebut sudah berubah, anakanak adalah usia yang paling mudah menerima informasi baru, mengadopsinya dan konsep baru tersebut kepada keluarga dan teman sebayanya. (GITEWS,2008). Bencana 911 di Amerika Serikat membantu reorientasi arah pendidikan keperawatan dan menekankan strategi praktis, prosedur operasi standar, dan pertanyaan yang sering diajukan untuk perawat. Penelitian yang masih terbatas tentang keperawatan bencana sangat diakui di dunia sehingga dibentuklah, World Society of Disaster Nursing (WSDN) didirikan pada tahun 2008 di Kobe, Jepang.(Zhi, 2010). Peran perawat sebagai peneliti dan educator menuntut perawat untuk selalu mengembangkan strategi yang efektif untuk meningkatkan program preventif khususnya di bidang keperawatan bencana.

Kartu pintar yang merupakan kartu yang berisi gambar-gambar biasanya digunakan anak sekolah dalam meningkatkan kemampuan membaca dan mengenal objek. Hasil penelitian Nugroho dan Utomo tahun 2015 tentang meningkatkan kemampuan membaca dengan menggunakan Media Smart Card pada Anak Kelompok B Taman KanakKanak Dharma Wanita Janti Kecamatan Papar Kabupaten Kediri menunjukkan bahwa terdapat peningkatan kemampuan membaca pada anak kelompok B TK Dharma Wanita Janti Kecamatan Papar Kabupaten Kediri setelah menggunakan 
kartu pintar membaca. Pengembangan kartu pintar mengenai penanggulangan bencana akan mulai dilakukan pada penelitian ini, dengan harapan strategi peningkatan sikap dalam menghadapi bencana dapat menjangkau sampai anak sekolah.

\section{METODE}

Desain penelitian menggunakan quasi experiment dengan pendekatan PretestPosttest Control Group Design. Pada penelitian ini terdapat dua kelompok, yaitu kelompok intervensi dan kelompok kontrol.

Semua responden dari dua kelompok diberikan kuesioner sebelum dilakukan intervensi. Setelah mengisi kuesioner pre test, kelompok intervensi diberikan aktivitas mengamati kartu selama lebih kurang 1 jam, kemudian diadakan pengukuran post test pada kedua kelompok. Penelitian ini dilakukan pada siswa sekolah dasar (SD) Negeri Taman Sukarya 1 dan 2 di Kota Tangerang.

\section{HASIL}

\section{Analisis Univariat}

Analisis univariat dilakukan untuk menggambarkan karakteristik responden yang meliputi usia dan jenis kelamin dan pengetahuan. Hasil analisis univariat dijelaskan dalam tabel sebagai berikut :
Tabel 1. Distribusi Frekuensi Responden berdasarkan usia di SD Negeri Taman Sukarya 1 dan 2 di Kota Tangerang ( $\mathrm{N}=100)$

\begin{tabular}{lccccc}
\hline Variabel & Mean & Median & SD & $\begin{array}{l}\text { Min- } \\
\text { Maks }\end{array}$ & P Value \\
\hline $\begin{array}{l}\text { Usia } \\
\text { Kel. }\end{array}$ & 10,10 & 10 & 0,416 & $9-11$ & 0,062 \\
$\begin{array}{l}\text { Intrvensi } \\
\begin{array}{l}\text { Kel } \\
\text { Kontrol }\end{array}\end{array}$ & 10,40 & 10 & 0,969 & $9-13$ & \\
\hline
\end{tabular}

Tabel 1 menunjukkan bahwa didapatkan rata-rata umur responden pada kelompok intervensi adalah 10,10 dengan standar deviasi 0,416 dan rata-rata kelompok kontrol adalah 10,40 dengan standar deviasi 0,969. Umur termuda adalah 9 dan tertua adalah 11 pada kelompok intervensi dan 13 pada kelompok kontrol. Pada variable usia telah dilakukan uji $\mathrm{T}$ dependent untuk melihat perbedaan usia antara 2 kelompok. Hasil analisis didapatkan nilai $p$ value $=$ 0,062 ( $\mathrm{p}$ value $<0,005$ ) sehingga dapat disimpulkan tidak ada perbedaan yang bermakna pada usia antara kelompok intervensi dan kelompok kontrol.Perbedaan yang bermakna pada usia antara kelompok intervensi dan kelompok kontrol.

Tabel 2. Distribusi Frekuensi Responden berdasarkan Jenis Kelamin di SD Negeri Taman Sukarya 1 dan 2 Kota Tangerang Tahun $2018(\mathrm{~N}=100)$

\begin{tabular}{lccccccc}
\hline $\begin{array}{l}\text { Variabel } \\
\text { Jenis } \\
\text { Kelamin }\end{array}$ & \multicolumn{2}{c}{ Perempuan } & \multicolumn{2}{c}{ Laki-laki } & Jumlah & $\begin{array}{l}\text { P } \\
\text { value }\end{array}$ \\
\cline { 2 - 6 } & $\mathbf{N}$ & $\%$ & $\mathbf{N}$ & $\%$ & $\mathbf{N}$ & $\%$ & \\
\hline $\begin{array}{l}\text { Kel. } \\
\text { Intrvensi }\end{array}$ & 23 & $46 \%$ & 27 & $54 \%$ & 50 & $100 \%$ & 0,345 \\
Kel. & 26 & $52 \%$ & 24 & $48 \%$ & 50 & $100 \%$ & \\
$\begin{array}{l}\text { Kontrol } \\
\text { Jumlah }\end{array}$ & 49 & $49 \%$ & 51 & $51 \%$ & 100 & $100 \%$ & \\
& & & & & & &
\end{tabular}


Tabel 2 menunjukkan distribusi frekuensi responden berdasarkan karakteritik jenis kelamin yaitu pada kelompok intervensi berjenis kelamin perempuan sebanyak 23 orang (46\%) dan laki-laki 27 orang (54\%). Pada kelompok kontrol responden berjenis kelamin perempuan sebanyak 26 orang (52\%) dan laki-laki 24 orang (48\%). Jumlah keseluruhan responden berjenis kelamin perempuan sebanyak 49 orang (49\%) dan laki-laki 51 orang (51\%). Pada analisis bivariate didapatkan nilai $p$ value $=0,345$, sehingga dapat disimpulkan tidak ada perbedaan jenis kelamin yang bermakna antar kelompok intervensi dan kelompok kontrol.

Tabel 3. Distribusi Frekuensi Responden berdasarkan Pengetahuan di SD Negeri

Taman Sukarya 1 dan 2 Kota Tangerang $(\mathrm{N}=100)$

\begin{tabular}{lccccc}
\hline $\begin{array}{l}\text { Variabel } \\
\text { Pengeta- } \\
\text { huan }\end{array}$ & $\begin{array}{c}\text { Belum } \\
\text { Tahu }\end{array}$ & $\begin{array}{c}\text { Sudah } \\
\text { Tahu }\end{array}$ & Jumlah & $\begin{array}{l}\text { P } \\
\text { value }\end{array}$ \\
\cline { 2 - 5 } & N $\%$ & N & $\%$ & N & $\%$
\end{tabular}

\begin{tabular}{lccccccc}
\hline $\begin{array}{l}\text { Kel. } \\
\text { Intrvensi }\end{array}$ & 26 & $52 \%$ & 24 & $48 \%$ & 50 & $100 \%$ & 0,069 \\
$\begin{array}{l}\text { Kel. } \\
\text { Kontrol }\end{array}$ & 17 & $34 \%$ & 33 & $66 \%$ & 50 & $100 \%$ & \\
\hline Jumlah & 43 & $43 \%$ & 57 & $57 \%$ & 100 & $100 \%$ &
\end{tabular}

Tabel 3 menunjukkan distribusi frekuensi responden berdasarkan karakteritik pengetahuan yaitu pada kelompok intervensi, responden yang belum tahu tentang bencana sebanyak 26 orang $(52 \%)$ dan yang sudah tahu tentang bencana berjumlah 24 orang (48\%). Pada kelompok kontrol responden yang belum tahu sebanyak 17 orang (34\%) dan yang sudah tahu tentang bencana 33 orang (66\%). Jumlah keseluruhan responden yang belum tahu tentang bencana adalah 43 orang (43\%) lebih sedikit dari pada yang sudah tahu yaitu 57 orang (57\%). Pada hasil analisis bivariate ditemukan nilai $\mathrm{p}$ value $=$ 0,069 yang berarti bahwa tidak terdapat perbedaan pengetahuan yang bemakna antara kelompok intervensi dan kelompok kontrol.

Tabel 4. Distribusi Frekuensi Responden Berdasarkan sikap kesiapsiagaan bencana sebelum intervensi di SD Negeri Taman Sukarya 1 dan 2 Tahun $2018(\mathrm{~N}=100)$

\begin{tabular}{|c|c|c|c|c|c|c|}
\hline \multirow{2}{*}{$\begin{array}{l}\text { Variabel } \\
\text { Sikap } \\
\text { Kesiap- } \\
\text { siagaan } \\
\text { bencana }\end{array}$} & \multicolumn{2}{|c|}{$\begin{array}{c}\text { Sikap } \\
\text { Negatif }\end{array}$} & \multicolumn{2}{|c|}{$\begin{array}{c}\text { Sikap } \\
\text { Positif }\end{array}$} & \multicolumn{2}{|c|}{ Jumlah } \\
\hline & $\mathbf{N}$ & $\%$ & $\mathbf{N}$ & $\%$ & $\mathbf{N}$ & $\%$ \\
\hline $\begin{array}{l}\text { Kel. } \\
\text { Intrvensi }\end{array}$ & 20 & $40 \%$ & 30 & $60 \%$ & 50 & $100 \%$ \\
\hline $\begin{array}{l}\text { Kel. } \\
\text { Kontrol }\end{array}$ & 23 & $46 \%$ & 27 & $54 \%$ & 50 & $100 \%$ \\
\hline Jumlah & 43 & $43 \%$ & 57 & $57 \%$ & 100 & $100 \%$ \\
\hline
\end{tabular}

Tabel 4. menunjukkan distribusi frekuensi responden berdasarkan karakteritik sikap kesiapsiagaan bencana sebelum intervensi yaitu pada kelompok intervensi, responden dengan sikap negatif sebanyak 20 orang (43\%) dan sikap positif 30 orang (60\%). Pada kelompok kontrol, responden dengan sikap negatif lebih sedikit yaitu 23 orang (46\%) dibanding sikap positif yaitu 27 orang (54\%). Jumlah keseluruhan responden yang memiliki sikap positif sebelum dilakukan intervensi adalah 57 orang. 
Tabel 5. Distribusi Frekuensi Responden Berdasarkan sikap kesiapsiagaan bencana sesudah intervensi di SD Negeri Taman Sukarya 1 dan 2 Kota Tangerang $(\mathrm{N}=100)$

\begin{tabular}{|c|c|c|c|c|c|c|}
\hline \multirow{2}{*}{$\begin{array}{l}\text { Variabel } \\
\text { Sikap } \\
\text { Kesiap- } \\
\text { siagaan } \\
\text { bencana }\end{array}$} & \multicolumn{2}{|c|}{$\begin{array}{l}\text { Sikap } \\
\text { Negatif }\end{array}$} & \multicolumn{2}{|c|}{$\begin{array}{l}\text { Sikap } \\
\text { Positif }\end{array}$} & \multicolumn{2}{|c|}{ Jumlah } \\
\hline & $\mathbf{N}$ & $\%$ & $\mathbf{N}$ & $\%$ & $\mathbf{N}$ & $\%$ \\
\hline $\begin{array}{l}\text { Kel. } \\
\text { Intrvensi }\end{array}$ & 20 & $40 \%$ & 30 & $60 \%$ & 50 & $100 \%$ \\
\hline $\begin{array}{l}\text { Kel. } \\
\text { Kontrol }\end{array}$ & 23 & $46 \%$ & 27 & $54 \%$ & 50 & $100 \%$ \\
\hline Jumlah & 43 & $43 \%$ & 57 & $57 \%$ & 100 & $100 \%$ \\
\hline
\end{tabular}

Tabel 5 menunjukkan distribusi frekuensi responden berdasarkan karakteritik sikap kesiapsiagaan bencana setelah intervensi yaitu pada kelompok intervensi, responden dengan sikap negatif sebanyak 20 orang (40\%) dan sikap positif 30 orang $(60 \%)$. Pada kelompok kontrol responden dengan sikap negative sebanyak 23 orang (46\%) dan sikap positif 27 orang (54\%). Jumlah responden yang memiliki sikap positif pada pengukuran kedua atau setelah intervensi tidak mengalami perubahan yaitu 57 orang.

Tabel 6. Distribusi rata-rata Sikap Kesiapsiagaan Bencana Sebelum dan Sesudah Mengamati kartu Bencana Pada Kelompok Intervensi

\begin{tabular}{lccccc}
\hline Variabel & Mean & $\begin{array}{l}\text { Standar } \\
\text { Deviasi } \\
\text { (SD) }\end{array}$ & SE & $\begin{array}{l}\text { P } \\
\text { Value }\end{array}$ & N \\
\hline $\begin{array}{l}\text { Sikap Pre } \\
\text { Intrvensi }\end{array}$ & 36,28 & 3,61 & 0,511 & 0,734 & 50 \\
$\begin{array}{l}\text { Sikap Post } \\
\text { Kontrol }\end{array}$ & 36,54 & 4,36 & 0,617 & & 50 \\
\hline
\end{tabular}

Tabel 6 menunjukkan rata-rata sikap sebelum diberikan intervensi adalah 36,28 dengan standar deviasi 3,61. Pada
Pengukuran kedua didapat rata-rata sikap setelah diberikan intervensi adalah 36,54 dengan standar deviasi 4,36. Terlihat nilai mean perbedaan antara pengukuran pertama dan kedua adalah 0,26 dengan standar deviasi 0,75 . Hasil uji statsitik diadapatkan nilai 0,734 maka dapat disimpulkan tidak ada perbedaan yang signifikan antara pengukuran sikap sebelum dan setelah dilaksanakan intervensi mengamati kartu.

Tabel 7. Distribusi rata-rata Sikap Kesiapsiagaan Bencana dengan Dua Kali Pengukuran Pada Kelompok Kontrol

\begin{tabular}{lccccc}
\hline Variabel & Mean & $\begin{array}{l}\text { Standar } \\
\text { Deviasi } \\
\text { (SD) }\end{array}$ & SE & $\begin{array}{l}\text { P } \\
\text { Value }\end{array}$ & N \\
\hline $\begin{array}{l}\text { Sikap Pre } \\
\text { Intrvensi }\end{array}$ & 36,96 & 4,408 & 0,623 & 0,475 & 50 \\
$\begin{array}{l}\text { Sikap Post } \\
\text { Kontrol }\end{array}$ & 36,30 & 3,986 & 0,564 & & 50 \\
\hline
\end{tabular}

Tabel 7 menunjukkan rata-rata sikap pada pengukuran pertama adalah 36,96 dengan standar deviasi 4,408. Pada Pengukuran kedua didapat rata-rata sikap setelah diberikan intervensi adalah 36,30 dengan standar deviasi 3,986. Terlihat nilai mean perbedaan antara pengukuran pertama dan kedua ternyata menurun adalah 0,66 dengan standar deviasi 0,059. Hasil uji statsitik diadapatkan nilai 0,475 maka dapat disimpulkan tidak ada perbedaan yang signifikan antara pengkuran pertama dan kedua pada kelompok kontrol. 
Tabel 8. Perbedaan rata-rata Sikap Kesiapsiagaan Bencana Setelah Membaca Komik Antara

Kelompok Intervensi dan Kontrol

\begin{tabular}{lccclc}
\hline Variabel & Mean & $\begin{array}{l}\text { Standar } \\
\text { Deviasi } \\
\text { (SD) }\end{array}$ & SE & $\begin{array}{l}\text { P } \\
\text { Value }\end{array}$ & $\mathbf{N}$ \\
\hline $\begin{array}{l}\text { Tanpa } \\
\text { kartu }\end{array}$ & 0,66 & 6,48 & 0,91 & 0,738 & 50 \\
$\begin{array}{l}\text { Dengan } \\
\text { Kartu }\end{array}$ & 0,26 & 5,39 & 0,76 & & 50 \\
\hline
\end{tabular}

Tabel 8 menunjukkan rata-rata selisih sikap pada kelompok yang tidak mengamati kartu (kontrol) adalah 0,66 dengan standar deviasi 6,48. Pada kelompok yang diberikan intervensi mengamati kartu didapat rata-rata selisih sikap adalah 0,26 dengan standar deviasi 5,39. Hasil uji statsitik diadapatkan nilai $P$ value 0,73 ( $P$ value $\geq 0,05)$ maka dapat disimpulkan tidak ada perbedaan yang signifikan antara rata-rata sikap kelompok intervensi dan kelompok kontrol.

\section{PEMBAHASAN}

\section{Karakteristik Reponden Penelitian}

Karakteristik responden pada penelitian ini terdiri dari usia, jenis kelamin dan pengetahuan responden. Hasil penelitian didapatkan rata-rata umur responden pada kelompok intervensi adalah 10,10 dengan standar deviasi 0,416 dan rata-rata kelompok kontrol adalah 10,40 dengan standar deviasi 0,969. Umur termuda adalah 9 dan tertua adalah 11 pada kelompok intervensi dan 13 pada kelompok kontrol. Pada variabel usia telah dilakukan uji $\mathrm{T}$ dependent untuk melihat perbedaan usia antara 2 kelompok. Hasil analisis didapatkan nilai $p$ value $=0,062(\mathrm{p}$ value $<$ 0,005) sehingga dapat disimpulkan tidak ada perbedaan yang bermakna pada usia antara kelompok intervensi dan kelompok kontrol. . Karaktersitik usia responden pada penelitian ini sudah homogen karena dibatasi dengan kriteria inklusi yaitu pada usia kelas 4-6 sekolah dasar ( lebih dari 10 tahun), sehingga rata-rata usia responden baik pada kelompok intervensi maupun kelompok kontrol adalah 10 tahun. Menurut Aprianto Richi Ledi dan Ningsih sukri dwi, 2016 bahwa masa usia 10-12 tahun merupakan masa perkembangan usia opearsional konkret, sehingga media yang diberikan untuk pembelajaran haruslah dengan media yang konkret seperti pengamatan kartu bergambar.

Karakteristik responden berdasarkan pengetahuan dikumpulkan berdasarkan data bahwa responden sudah pernah mendapatkan pengetahuan baik berupa pelajaran ataupun simulasi di sekolah dan di luar sekolah. Variabel dibagi menjadi dua kategori yaitu belum tahu dan sudah tahu. Tabel 5.3 menunjukkan distribusi frekuensi responden berdasarkan karakteritik pengetahuan yaitu pada kelompok intervensi, responden yang belum tahu tentang bencana sebanyak 26 orang $(52 \%)$ dan yang sudah tahu tentang bencana berjumlah 24 orang (48\%). Pada 
kelompok kontrol responden yang belum tahu sebanyak 17 orang (34\%) dan yang sudah tahu tentang bencana 33 orang (66\%). Jumlah keseluruhan responden yang belum tahu tentang bencana adalah 43 orang (43\%) lebih sedikit dari pada yang sudah tahu yaitu 57 orang (57\%). Pada hasil analisis bivariate ditemukan nilai $\mathrm{p}$ value $=0,069$ yang berarti bahwa tidak terdapat perbedaan pengetahuan yang bemakna antara kelompok intervensi dan kelompok kontrol. Hasil ini disebabkan karena pada saat pemilihan sampel responden dilakukan secara konsekutiv sehingga pemilihan responden hanya didasarkan pada kriteria inklusi. Pada penelitian ini pengetahuan tidak dimasukkan ke dalam kriteria inklusi, sehingga variasi antara responden yang sudah pernah belajar atau tahu tentang bencana dan yang belum tidak diketahui sebelumnya.

Responden yang termasuk pada kategori sudah tahu, mendapatkan pengetahuan bencana dari pelajaran sekolah. Guru sekolah mengatakan bahwa pelajaran yang diberikan kepada murid masih diberikan dengan metode konvensional melalui buku pelajaran yang disajikan secara abstrak. Terbentuknya sikap yang baik sangat dipengaruhi oleh pengetahuan. Tujuan pentingnya pendidikan kebencanaan adalah untuk menanamkan sikap tanggap dan responsif terhadap bencana sehingga sehingga risiko yang fatal bisa dihindari dan memahami tentang bencana, tetapi yang lebih utama adalah bagaimana mereka menghadapi risiko bencana dengan sikap siaga dan responsive sehingga meminimalkan dampak yang parah. (Husna Cut, 2012).

\section{Perbedaan Sikap Kesiapsiagaan} Bencana pada Kelompok Intervensi dan Kelompok Kontrol

Tabel 3 menunjukkan distribusi frekuensi responden berdasarkan karakteritik sikap kesiapsiagaan bencana setelah intervensi yaitu pada kelompok intervensi, responden dengan sikap negatif sebanyak 20 orang (43\%) dan sikap positif 30 orang $(60 \%)$. Pada kelompok kontrol, responden dengan sikap negatif lebih sedikit yaitu 23 orang (46\%) dibanding sikap positif yaitu 27 orang (54\%). Jumlah keseluruhan responden yang memiliki sikap positif sebelum dilakukan intervensi adalah 57 orang. Pada analisis univariat dapat dilihat bahwa tidak terdapat perbedaan sikap pada kelompok intervensi dan kontrol. Pada pengamatan data individu, responden yang memiliki perubahan nilai dari sikap positif dan negative adalah individu yang berbeda, namun pada saat jumlah kelompok tetap antara sebelum dan setelah intervenasi. 
Pemakaian media dalam proses pembelajaran dapat membangkitkan keinginan dan minat yang baru, membangkitkan motivasi, dan memberikan rangsangan kegiatan belajar, bahkan pengaruh-pengaruh psikologis pada anak. Media akan dapat menarik perhatian minat anak dan akhirnya berkonsentrasi untuk belajar dan memahami pelajaran (Hamalik dalam Arsyad, 2006, dalam sessiani 2007). Pendidikan tanggap bencana untuk anakanak seharusnya mempunyai media yang berbeda dengan orang dewasa dalam menyampaikannya. Namun selama ini pendidikan tanggap bencana masih dijadikan satu bab dan dimasukkan pada salah satu mata pelajaran di sekolah. Cara ini terkesan membosankan bagi anak-anak karena tidak semua anak-anak suka membaca apalagi membaca buku sekolah (www.elib.unikom.ac.id). Melalui media gambar pesan dapat dituangkan melalui symbol-simbol komunikasi visual media gambar diharapkan dapat menggairahkan dan memberikan motivasi kepada siswa untuk ikut berpertisipasi secara aktif dan berinteraksi dalam proses pembelajaran (Suyuthi,2011).

Pada analisis bivariate dilakukan dengan menggunakan uji $\mathrm{T}$ dependent setelah dilakukan uji normalitas, untuk mengetahui perbedaan rerata pada responden dengan kelompok yang sama. Tabel 5.6 menunjukkan rata-rata sikap sebelum diberikan intervensi adalah 36,28 dengan standar deviasi 3,61. Pada Pengukuran kedua didapat rata-rata sikap setelah diberikan intervensi adalah 36,54 dengan standar deviasi 4,36. Terlihat nilai mean perbedaan antara pengukuran pertama dan kedua adalah 0,26 dengan standar deviasi 0,75. Hasil uji statsitik diadapatkan nilai 0,734 maka dapat disimpulkan tidak ada perbedaan yang signifikan antara pengukuran sikap sebelum dan setelah dilaksanakan intervensi mengamati kartu.

Tabel 7 menunjukkan rata-rata sikap pada pengukuran pertama adalah 36,96 dengan standar deviasi 4,408. Pada Pengukuran kedua didapat rata-rata sikap setelah diberikan intervensi adalah 36,30 dengan standar deviasi 3,986. Terlihat nilai mean perbedaan antara pengukuran pertama dan kedua ternyata menurun adalah 0,66 dengan standar deviasi 0,059. Hasil uji statsitik diadapatkan nilai 0,475 maka dapat disimpulkan tidak ada perbedaan yang signifikan antara pengkuran pertama dan kedua pada kelompok kontrol.

Pada kelompok intervensi didapatkan perbedaan rerata pada pengkuran sebelum dan setelah intervensi. Peningkatan ratarata nilai sikap bisa terkait dengan pengetahuan yang telah diperoleh responden setelah mengamati kartu pintar bencana. Hal ini berbeda dengan kelompok kontrol dimana rata-rata nilai sikap menurun 0,66. Kelompok kontrol hanya 
diberikan kuesioner sikap tanpa diberikan pengetahuan tambahan dengan intervensi mengamati kartu. Konsep kartu pintar bencana hampir sama dengan kartu pintar yang biasa digunakan oleh anak-anak sekolah dasar untuk meningkatkan kemampuan dalam membaca, saat mengenal huruf dan melihat gambar. Hal ini sesuai dengan penelitian Utami Delfi Citra (2017) tentang pengaruh penggunaan media kartu huruf terhadap kemampuan membaca permulaan siswa kelas1 SD Negeri 1 Rajabasa Raya Bandar Lampung, dimana didapatkan rata-rata hasil belajar siswa di kelas eksperimen lebih tinggi dibanding kelas kontrol.

Namun demikian, pada kedua kelompok baik intervensi dan kontrol tidak terdapat perbedaan yang signifkan hal ini diasumsikan bahwa pemaparan kartu bencana hanya diberikan pada waktu yang singkat sehingga perbedaan rata-rata antara sebelum dan setelah intervensi tidak memberikan perbedaan yang bermakna.

\section{Pengaruh Kartu Pintar Bencana}

\section{Terhadap Sikap Kesiapsiagaan Bencana}

Pengaruh kartu pintar bencana terhadap sikap kesiapsiagaan bencana diukur dengan membandingkan nilai rata-rata pada kelompok intervensi dan kelompok kontrol dengan melakukan analisis uji $t$ independent.
Tabel 8 menunjukkan rata-rata selisih sikap pada kelompok yang tidak mengamati kartu (kontrol) adalah 0,66 dengan standar deviasi 6,48. Pada kelompok yang diberikan intervensi mengamati kartu didapat rata-rata selisih sikap adalah 0,26 dengan standar deviasi 5,39. Hasil uji statsitik diadapatkan nilai $P$ value 0,73 ( $P$ value $\geq 0,05$ )maka dapat disimpulkan tidak ada perbedaan yang signifikan antara ratarata sikap kelompok intervensi dan kelompok kontrol.

Hasil penelitian tidak sesuai dengan penelitian sebelumnya dimana banyak penggunaan kartu pintar bergambar yang digunakan untuk meningkatkan kemampuan baca pada anak sekolah dasar. Penelitian Meha Nehru dan Hengelina, 2017 tentang pengaruh penggunaan media kartu kata terhadap kemampuan membaca permulaan anak usia 5-6 tahun di BIMBA AIUEO unit Alinda Bekasi Utara mendapatkan hasil mean skor yang lebih tinggi 47,80 pada kelompok intervensi dibanding kelompok kontrol 41,67.

Pengertian kartu menurut Kamus Besar Bahasa Indonesia adalah kertas tebal berbentuk persegi panjang, sedangkan kata adalah unsur bahasa yang diucapkan atau dituliskan yang merupakan perwujudan kesatuan perasaan dan pikiran yang dpat digunakan dalam berbahasa. Gambar merupakan media yang paling umum dipakai. Jadi kartu bergambar adalah kartu 
yang berisi kata-kata dan terdapat gambar. Adapun kelebihan dalam kartu bergambar menurut Dina Indriana tahun 2011 dalam Arifah, 2012 antara lain mudah dibawa kemana-mana, praktis dalam membuat dan menggunakannya, sehingga kapan pun anak didik bisa belajar dengan baik menggunakan kartu media ini, gampang diingat karena kartu ini bergambar yang sangat menarik perhatian dan menyenangkan sebagai media pembelajaran, bahkan bisa digunakan dalam permainan. Pemakaian media dalam proses pembelajaran dapat membangkitkan keinginan dan minat yang baru, membangkitkan motivasi, dan memberikan rangsangan kegiatan belajar, bahkan pengaruh-pengaruh psikologis pada anak. Media akan dapat menarik perhatian minat anak dan akhirnya berkonsentrasi untuk belajar dan memahami pelajaran (Hamalik dalam Arsyad, 2006, dalam sessiani 2007).

Pada hasil penelitian Dwiyanti Retno, 2013 proses penggunaan kartu kata diikuti dengan proses permainan yang telah disusun bersama guru yaitu antara lain kegiatan membaca cerita bergambar, anakanak berlomba mencari sejumlah kartu kata sesuai dengan permintaan guru, kemudian anak diminta membaca kartu kata. Setelah selesai anak mendapatkan pujian berupa stiker emoticon smile. Proses permainan seperti hasil penelitian tersebut belum dilaksanakan maksimal pada penelitian ini.
Proses pemberian kartu, hanya diberikan petunjuk sesuai hal-hal yang harus dilakukan responden, tanpa proses permainan dan pemberian pujian.

\section{SIMPULAN}

Hasil Penggunaan Karu Pintar tidak ada perbedaan yang signifikan antara rata-rata sikap kelompok intervensi dan kelompok kontrol. Kartu bencana dapat digunakan sebagai wahana baca dan permainan yang mengandung informasi tentang bencana walaupun tidak meningkatkan sikap kesiapsiagaan bencana pada anak sekolah dasar.

\section{DAFTAR PUSTAKA}

Anonim $^{\text {a }}$, 2016, Pengaruh Pengetahuan, Sikap dan Kesiapsiagaan Rumah Tangga Dalam Menghadapi Bencana Gempa Bumi Di Desa Deyah Raya Kecamatan Syiah Kuala Kota Banda Aceh diakses dari http://repository.usu.ac.id/bidstream/h andle tanggal 12 April 2017

Aprianto Richi Ledi, Ningsih Sukri Dwi, 2016, Pengaruh Media Pembelajaran Komik Terhadap Hasil Belajar IPS Materi Bencana Alam Siswa Kelas VI Sekolah Dasar, Jurnal Penelitian Pendidikan, Vol.8 Nomor 1, Juni 2016, hlm1189-1249. Jakarta

Arifah W, 2012, Media Kartu Bergambar, diakses dari eprints.uny.ac.id. tanggal 17 Okotber 2017

BNPB, 2008, Peraturan Kepala Badan Nasional Penanggulangan Bencana No.4 Tahun 2008 Tentang Pedoman Penyusunan Rencana Penanggulangan Bencana, diakses dari https://BNPB.go.id>migration>pubs tanggal 11 April 2017

Clust, Michael, RJ. Human, dan DM. Simpson. 2007.Mapping and rail safety: the 
Development of Mapping Display Technology for Data Communication. Center for Hazards Research and Policy Development.

Connor SB, 2014, Factors Associated with the Intention of Health Care Personnel to Respond to a Disaster. Diakses dari http://www.ncbi.nlm.nih.gov/pubmed/2 5384396 tanggal 28 Maret 2017.

Cedri $\mathrm{S}$ et all, 2015, Development of an Effective Communication Strategy for the Prevention of Burns in Children: the Prius Project, diakses dari https://www.ncbi.nlm.nih.gov/pubmed l?term=DISASTER+COMIC tanggal 10 April 2017

Codeanu TA, Celenza A, Jacobs, 2014 ,Does disaster education of teenagers translate into better survival knowledge, knowledge of skills, and adaptive behavioral change? A systematic literature review..Prehosp Disaster Med. 2014 Dec;29(6):629-42. doi: $10.1017 /$ S1049023X14001083. Epub 2014 Oct 20 diakses dari https://www.ncbi.nlm.nih.gov/pubmed l, tanggal 10 April 2017

Djafar M I, Mantu F N, Patellongi I J. 2013. Pengaruh Tentang Kesiapsiagaan Bencana Banjir Terhadap Pengetahuan dan Sikap Kepala Keluarga di Desa Romang Tangaya Kelurahan Tamangapa Kecamata Manggala Kota Makassar. Laporan Penelitian. Makassar.

Duong, Karen.(2009). Disaster Education and training on emergency nurses in South Australia. Australian Emergency Nursing Journal. Australia.

Dwiarti Retno, 2013, Peningkaan Kemampuan membaca Permulaan Menggunakan Permainan Kartu Kata Pada Anak Kelompok B TK Masyitoh Ngasem Sewon Bantul Yogyakarta, Skripsi UNY, Yogyakarta.

German-Indonesia Cooperation for Tsunami Early Warning System (GITEWS),
2008, Capacity Buliding in Local Communities, Jakarta, Indonseia

Liliani Else, 2015, Pemanfaatan Sastra Anak Sebagai Media Mitigasi Bencana, diakses dari http://staffnew.uny.ac.id/upload/13229 9491/penelitian/ABSTRAK+ PEMANFAATAN+SASTRA+ANAK +SEBAGAI+MEDIA+MITIGASI+B ENCANA.pdf, tanggal 10 April 2017

Meha Nehru, Hengelina, 2017, Pengaruh Penggunaan Media Kartu Kata Bergambar Terhadap Kemampuan Membaca Permulaan Anak Usia 5-6 tahun di BIMBA AIUEO Untuk Alinda Bekasi Utara, diakses dari journal.umj.ac.id tanggal 16 November 2018

Nugroho Isfauzi Hadi, Utomo Hanggara B, 2015, Meningkatkan Kemampuan Membaca Dengan Menggunakan Media Samrt Card Pada Anak Kelompok B Taman Kanak-Kanak Dharma Wanita Janti Kevamatan Papar Kabupaten Kediri, Skripsi, Kediri, Indonesia

Sinha,et all, 2011, Comic Books can Educate Children about Burn Safety in Developing Countries, diakses dari https://www.ncbi.nlm.gov>pubmed tanggal 12 April 2017

Tatalovic, M, 2009, Science Comic As Tools for Science Education and Communication, A Brief, Explanatory Study. JCOM Journal of Science Communication Volume 08(04):1-17.

Wikipedia, 2017, Komik, diakses dari https://id.m.wikipedia.org/komik tanggal 11 April 2017

Zhi Hu Li Za , 2010, Disaster and Disaster Nursing From an education and research Perspective, Juni; 57 (3): 116 diakses dari https://www.ncbi.nlm.nih.gov/pubmed 120535673 tanggal 19 Oktober 2017. 